\title{
Effect of Low pH on Carbohydrate Production by a Marine Planktonic Diatom (Chaetoceros muelleri)
}

\author{
Daniel C. O. Thornton \\ Department of Oceanography, College of Geosciences, Texas AઐM University, Eller OßM Building, \\ College Station, TX 77843-3146, USA \\ Correspondence should be addressed to Daniel C. O. Thornton, dthornton@ocean.tamu.edu
}

Received 5 November 2008; Accepted 28 January 2009

Recommended by Patricia Mosto

\begin{abstract}
Rising carbon dioxide $\left(\mathrm{CO}_{2}\right)$ concentrations in the atmosphere due to human activity are causing the surface ocean to become more acidic. Diatoms play a pivotal role in biogeochemical cycling and ecosystem function in the ocean. $\mathrm{pH}$ affected the quantum efficiency of photosystem II and carbohydrate metabolism in a planktonic diatom (Chaetoceros muelleri), representative of a widely distributed genus. In batch cultures grown at low $\mathrm{pH}$, the proportion of total carbohydrate stored within the cells decreased and more dissolved carbohydrates were exuded from the cells into the surrounding medium. Changes in productivity and the way in which diatoms allocate carbon into carbohydrates may affect ecosystem function and the efficiency of the biological carbon pump in a low $\mathrm{pH}$ ocean.
\end{abstract}

Copyright $\odot 2009$ Daniel C. O. Thornton. This is an open access article distributed under the Creative Commons Attribution License, which permits unrestricted use, distribution, and reproduction in any medium, provided the original work is properly cited.

\section{Introduction}

Rising carbon dioxide $\left(\mathrm{CO}_{2}\right)$ concentrations in the atmosphere due to human activity are causing the ocean to become more acidic [1]. The $\mathrm{pH}$ of the upper ocean has decreased from a preindustrial value of 8.2 to approximately 8.1 today [1]. It is estimated that the $\mathrm{pH}$ of ocean surface waters will be 7.9 by the end of this century and 7.4 by the end of the millennium [2]. Despite the global biogeochemical significance of primary production by diatoms, little is known about how they will respond to the decreasing $\mathrm{pH}$ of the ocean. The carbohydrate glucan is the primary storage compound in diatoms for carbon fixed during photosynthesis. Moreover, diatoms exude a proportion of their photosynthate into the surrounding medium as extracellular carbohydrates. The objective of this research was to determine how seawater $\mathrm{pH}$ affects growth, photosynthesis, and carbohydrate metabolism in a common diatom.

\section{Materials and Methods}

Chaetoceros muelleri (Lemmermann) (CCMP 1316) was grown at $\mathrm{pH} 6.8,7.4,7.9$, and 8.2. Cultures grown at $\mathrm{pH} 6.8$ represented an extreme beyond the current predictions for future ocean $\mathrm{pH}$ [2]. Batch cultures were grown in artificial seawater salt base [3] to which nutrients, trace metals, and vitamins were added as an $\mathrm{f} / 2$ enrichment [4]. Cultures were grown at $20^{\circ} \mathrm{C}$ under a photosynthetic photon flux density of $50 \mu \mathrm{mol} \mathrm{m}{ }^{-2} \mathrm{~s}^{-1}$, with a 14-hour daily light period. $\mathrm{pH}$ was maintained within the cultures using a biological buffer (25 mM HEPES (Sigma-Aldrich, St. Louis, Mo, USA)) and by daily titration with a small amount $(<100 \mu \mathrm{L})$ of $1 \mathrm{M} \mathrm{HCl}$.

Growth each day was followed in the cultures using in vivo chlorophyll fluorescence measured in a small sample $(200 \mu \mathrm{L})$ using a spectrofluorometer plate reader (Molecular Devices, Sunnyvale, Calif, USA).

The six replicate cultures grown at each $\mathrm{pH}$ were extensively sampled during exponential growth phase on day 5 . Samples were taken for cell counts [4] and chlorophyll $a$ concentrations [5]. The maximum quantum efficiency of photosystem II $\left(F_{v} / F_{m}\right)$ in Chaetoceros muelleri was measured in dark adapted ( 2 hours) cultures using a pulse amplitudemodulated (PAM) fluorometer (Heinz Walz, Effeltrich, Germany) [6]. Carbohydrates were measured using the phenol-sulfuric acid assay calibrated with D-glucose [7]. Fractionation and extraction of the different carbohydrate 


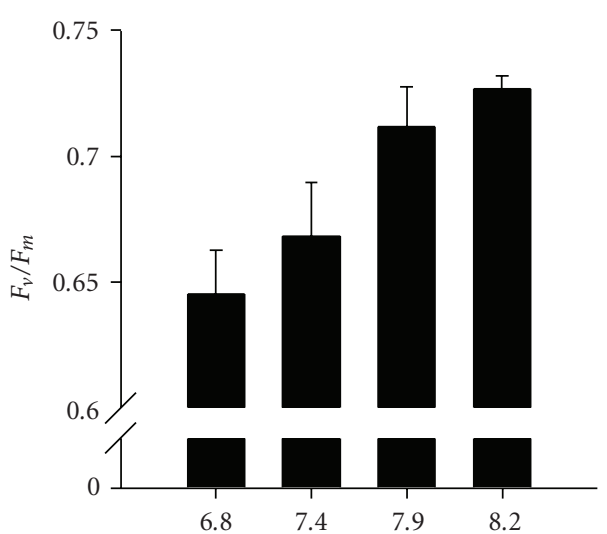

(a)

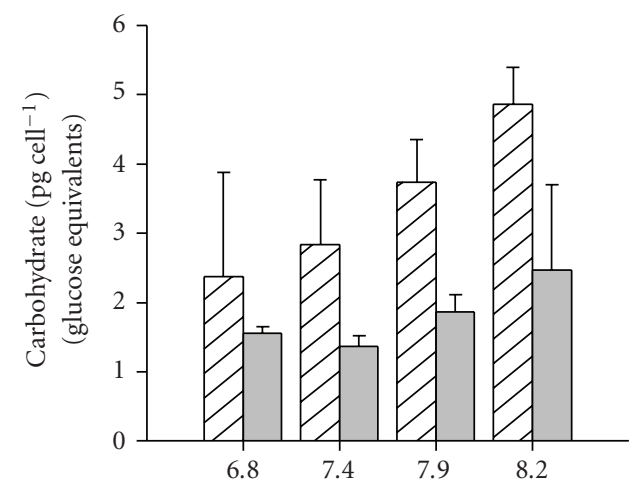

Cell (non-storage) Storage

(c)

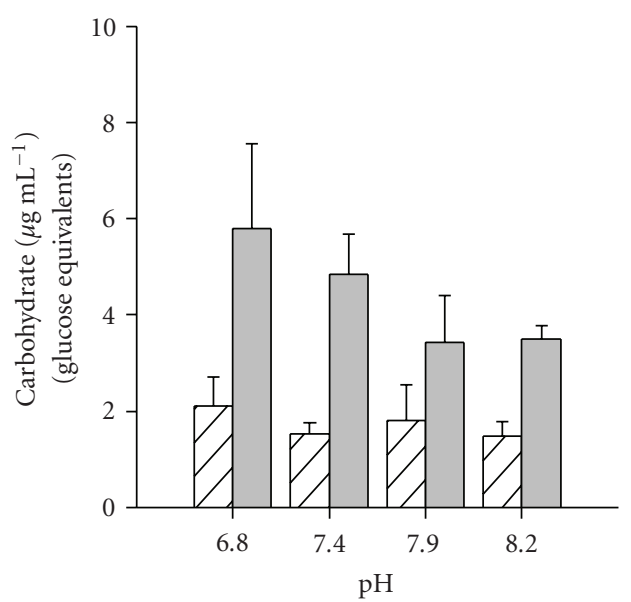

$\square$ Exopolymer

$\square$ Extracellular (non-exopolymer)

(e)

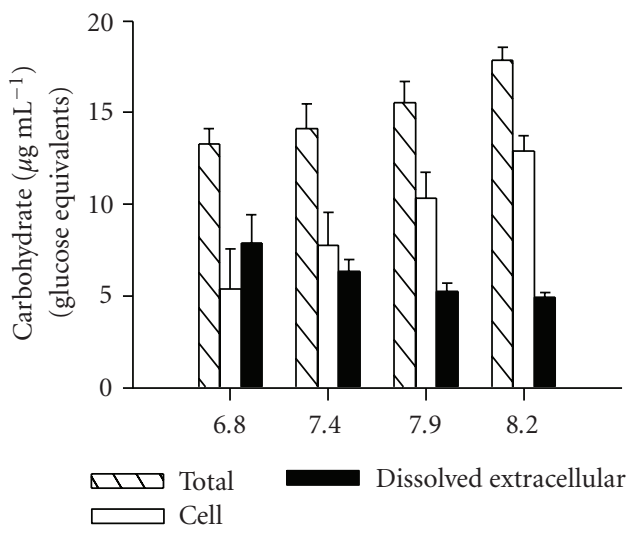

(b)

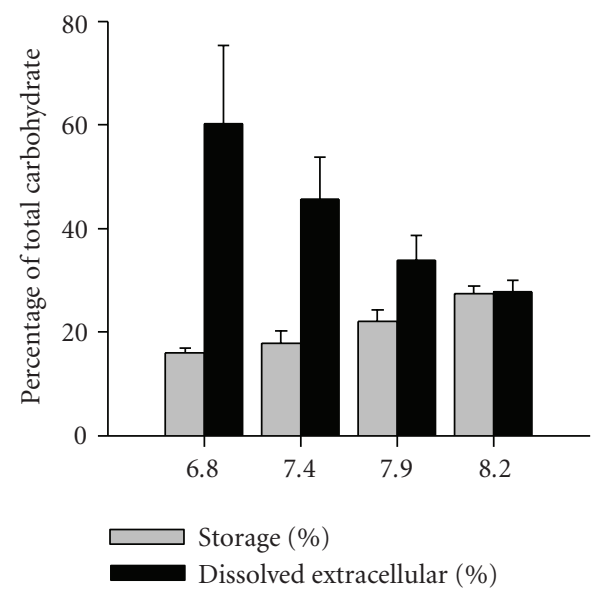

(d)

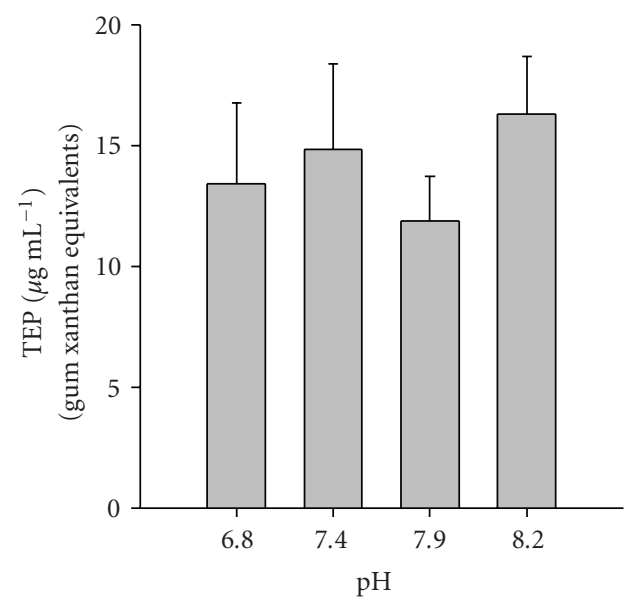

(f)

Figure 1: Effect of medium $\mathrm{pH}$ on photosynthesis and carbohydrate metabolism in Chaetoceros muelleri. Samples taken after 5 days growth in batch culture. (a) Maximum quantum efficiency of photosystem II $\left(F_{v} / F_{m}\right)$. (b) Total, cell and dissolved extracellular carbohydrate concentrations. (c) Cell-associated carbohydrates. (d) Proportion of carbohydrates in the dissolved extracellular and cell storage pools. (e) Extracellular carbohydrate pools. (f) Concentration of transparent exopolymer particles (TEP). Bars show mean + standard deviation ( $n=6$ replicate cultures). 
TABLE 1: Chaetoceros muelleri biomass and growth. Actual $\mathrm{pH}$ was the $\mathrm{pH}$ measured over the course of 6 days in culture. Growth rate derived from changes in in vivo chlorophyll fluorescence between days 2 and 5 . Biomass is expressed as diatom concentration (cells $\mathrm{mL}^{-1}$ ) and chlorophyll $a$ (chl. $a$ ) concentration $\left(\mu \mathrm{g} \mathrm{L}^{-1}\right)$. These data were used to calculate chl. $a$ content per cell (fg cell $\left.{ }^{-1}\right)$ on day 5 . Values are means \pm standard deviation ( $n=6$ replicate cultures).

\begin{tabular}{|c|c|c|c|c|c|c|}
\hline $\mathrm{pH}$ & Actual pH & Growth rate $\left(\mu^{\prime}\right)$ & Doubling time (days) & Cells $\mathrm{mL}^{-1}$ & chl. $a\left(\mu \mathrm{g} \mathrm{L}^{-1}\right)$ & chl. $a\left(\right.$ fg cell $\left.^{-1}\right)$ \\
\hline 6.8 & $6.82 \pm 0.04$ & $0.19 \pm 0.01$ & $1.55 \pm 0.05$ & $1.36 \times 10^{6} \pm 6.89 \times 10^{4}$ & $518 \pm 89$ & $378 \pm 50$ \\
\hline 7.4 & $7.42 \pm 0.04$ & $0.24 \pm 0.02$ & $1.27 \pm 0.10$ & $1.83 \times 10^{6} \pm 9.26 \times 10^{4}$ & $687 \pm 141$ & $375 \pm 76$ \\
\hline 7.9 & $7.93 \pm 0.04$ & $0.25 \pm 0.01$ & $1.22 \pm 0.03$ & $1.84 \times 10^{6} \pm 8.84 \times 10^{4}$ & $644 \pm 80$ & $351 \pm 45$ \\
\hline 8.2 & $8.23 \pm 0.05$ & $0.25 \pm 0.01$ & $1.20 \pm 0.07$ & $1.65 \times 10^{6} \pm 8.08 \times 10^{4}$ & $637 \pm 68$ & $388 \pm 55$ \\
\hline
\end{tabular}

pools were carried out using established methods $[8,9]$. Transparent exopolymer particles (TEP) were quantified according to [10].

\section{Results and Discussion}

Acid titration was used to maintain the desired $\mathrm{pH}$ [11], which tended to drift upward due to the removal of aqueous $\mathrm{CO}_{2}$ during photosynthesis. Future work should aim to decrease the $\mathrm{pH}$ by bubbling $\mathrm{CO}_{2}$-enriched air through seawater [12], which both reduces $\mathrm{pH}$ and increases the dissolved inorganic carbon (DIC) concentration. This simulates the effect of rising atmospheric $p \mathrm{CO}_{2}$ and provides control over DIC concentration.

Photosynthesis was affected by $\mathrm{pH}$ as determined by $F_{v} / F_{m}$ (see Figure $\left.1(\mathrm{a})\right) . F_{v} / F_{m}$ was inversely correlated with seawater $\mathrm{pH}(r=0.90, P<.001, n=24)$. These data show that the photosynthetic efficiency of $C$. muelleri decreases as the environment surrounding the cells becomes more acidic. Therefore, less energy was available to the cells to fix carbon at relatively low $\mathrm{pH}$. Growth rate was not affected by $\mathrm{pH}$ between 7.4 and 8.2; however, growth rate at $\mathrm{pH} 6.8$ was significantly lower (analysis of variance; $F_{3,20}=24.2, P<$ .001) (see Table 1).

Total carbohydrate was the greatest in cultures grown at the preindustrial $\mathrm{pH}$ of 8.2 (see Figure $1(\mathrm{~b})$ ). There was a significant decrease in total $\left(F_{3,20}=21.6, P<.001\right)$ and cell $\left(F_{3,20}=22.7, P<.001\right)$ carbohydrate as the diatoms were grown at lower $\mathrm{pH}$. In contrast, there was a significant increase (Kruskal-Wallis ANOVA; $H=18.6,3$ degrees of freedom, $P<.001)$ in dissolved extracellular carbohydrates with decreasing $\mathrm{pH}$. The ratio of cell carbohydrate to dissolved extracellular carbohydrate was $2.60 \pm 0.26$ (mean $\pm \mathrm{SD}$ ) at $\mathrm{pH} 8.2$; decreasing to $1.99 \pm 0.41$ at $\mathrm{pH} 7.9$, and $1.24 \pm 0.41$ at $\mathrm{pH} 7.4\left(F_{3,20}=30.3, P<.001\right)$. There was a significant difference $\left(F_{3,19}=6.55, P=.003\right)$ in non-storage cell carbohydrates at different growth $\mathrm{pH}$ (see Figure 1(c)).

As $\mathrm{pH}$ decreased, a decreasing proportion of the total carbohydrate was stored within the cells as glucan, and a greater proportion of the total carbohydrate was exuded from the cells (see Figure 1(d)). There was a significant inverse correlation between $\mathrm{pH}$ and the ratio of dissolved extracellular carbohydrate to glucan $(r=0.91, n=$ $23, P<.001)$. The increase in dissolved extracellular carbohydrate concentrations with decreasing $\mathrm{pH}$ was mainly in the form of low molecular weight carbohydrates rather than exopolymers (see Figure 1(e)). This is supported by the measurements of transparent exopolymer particle (TEP) concentrations within the cultures, which were not significantly different at different $\mathrm{pH}$ (see Figure 1(f)).

The shift in carbon allocation to different pools by diatoms at low $\mathrm{pH}$ may have implications for the ecosystem function, the efficiency of the biological carbon pump, and the resulting sequestration of $\mathrm{CO}_{2}$ in the deep ocean [13]. Less carbohydrate stored within the cells, and a greater production of low-molecular-weight dissolved extracellular carbohydrates at low $\mathrm{pH}$, will result in less particulate organic carbon in the water column, potentially reducing the efficiency of the biological carbon pump during diatom blooms. The reduction in $F_{v} / F_{m}$ and the increase in the proportion of carbohydrates exuded from the cells suggest that low $\mathrm{pH}$ affects membrane function in Chaetoceros muelleri. Thylakoid membrane integrity is vital to maintain photosynthetic capability and the plasmalemma controls exchange between the intra- and extracellular environments. Further work, including larger-scale mesocosm experiments in situ, will be needed to test these hypotheses.

\section{Acknowledgment}

Daniel C. O. Thornton acknowledges the support for this research from the Division of Ocean Sciences of the National Science Foundation (OCE 0726369).

\section{References}

[1] Royal Society, Ocean Acidification Due to Increasing Atmospheric Carbon Dioxide, Royal Society, London, UK, 2005.

[2] K. Caldeira and M. E. Wickett, "Oceanography: anthropogenic carbon and ocean pH," Nature, vol. 425, no. 6956, p. 365, 2003.

[3] J. A. Berges, D. J. Franklin, and P. J. Harrison, "Evolution of an artificial seawater medium: improvements in enriched seawater, artificial water over the last two decades," Journal of Phycology, vol. 37, no. 6, pp. 1138-1145, 2001.

[4] R. A. Andersen, Ed., Algal Culturing Techniques, Academic Press, Burlington, Mass, USA, 2005.

[5] L. J. Stal, H. van Gemerden, and W. E. Krumbein, "The simultaneous assay of chlorophyll and bacteriochlorophyll in natural microbial communities," Journal of Microbiological Methods, vol. 2, no. 6, pp. 295-306, 1984.

[6] K. Maxwell and G. N. Johnson, "Chlorophyll fluorescence-a practical guide," Journal of Experimental Botany, vol. 51, no. 345, pp. 659-668, 2000. 
[7] M. Dubois, K. A. Gilles, J. K. Hamilton, P. A. Rebers, and F. Smith, "Colorimetric method for determination of sugars and related substances," Analytical Chemistry, vol. 28, no. 3, pp. 350-356, 1956.

[8] D. J. Smith and G. J. C. Underwood, "Exopolymer production by intertidal epipelic diatoms," Limnology and Oceanography, vol. 43, no. 7, pp. 1578-1591, 1998.

[9] M. D. Apoya-Horton, L. Yin, G. J. C. Underwood, and M. R. Gretz, "Movement modalities and responses to environmental changes of the mudflat diatom Cylindrotheca closterium (Bacillariophyceae)," Journal of Phycology, vol. 42, no. 2, pp. 379390, 2006.

[10] U. Passow and A. L. Alldredge, "A dye-binding assay for the spectrophotometric measurement of transparent exopolymer particles (TEP)," Limnology and Oceanography, vol. 40, no. 7, pp. 1326-1335, 1995.

[11] U. Riebesell, A. T. Revill, D. G. Holdsworth, and J. K. Volkman, "The effects of varying $\mathrm{CO}_{2}$ concentration on lipid composition and carbon isotope fractionation in Emiliania huxleyi," Geochimica et Cosmochimica Acta, vol. 64, no. 24, pp. 4179-4192, 2000.

[12] M. D. Iglesias-Rodriguez, P. R. Halloran, R. E. M. Rickaby, et al., "Phytoplankton calcification in a high- $\mathrm{CO}_{2}$ world," Science, vol. 320, no. 5874, pp. 336-340, 2008.

[13] U. Riebesell, K. G. Schulz, R. G. J. Bellerby, et al., "Enhanced biological carbon consumption in a high $\mathrm{CO}_{2}$ ocean," Nature, vol. 450, no. 7169, pp. 545-548, 2007. 

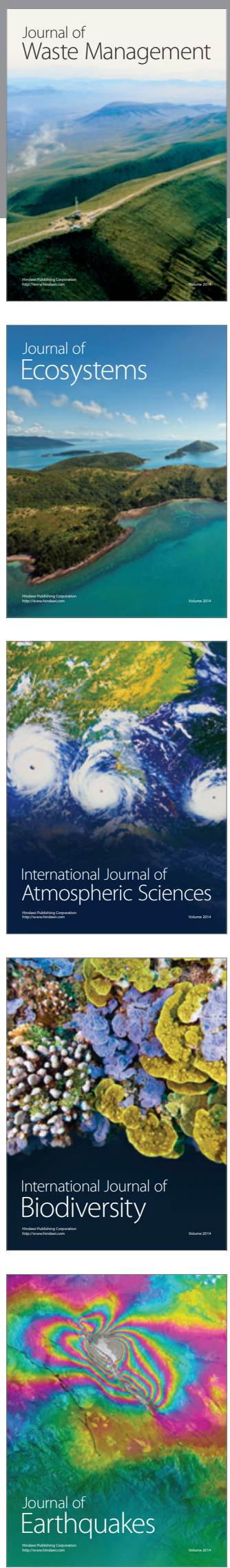
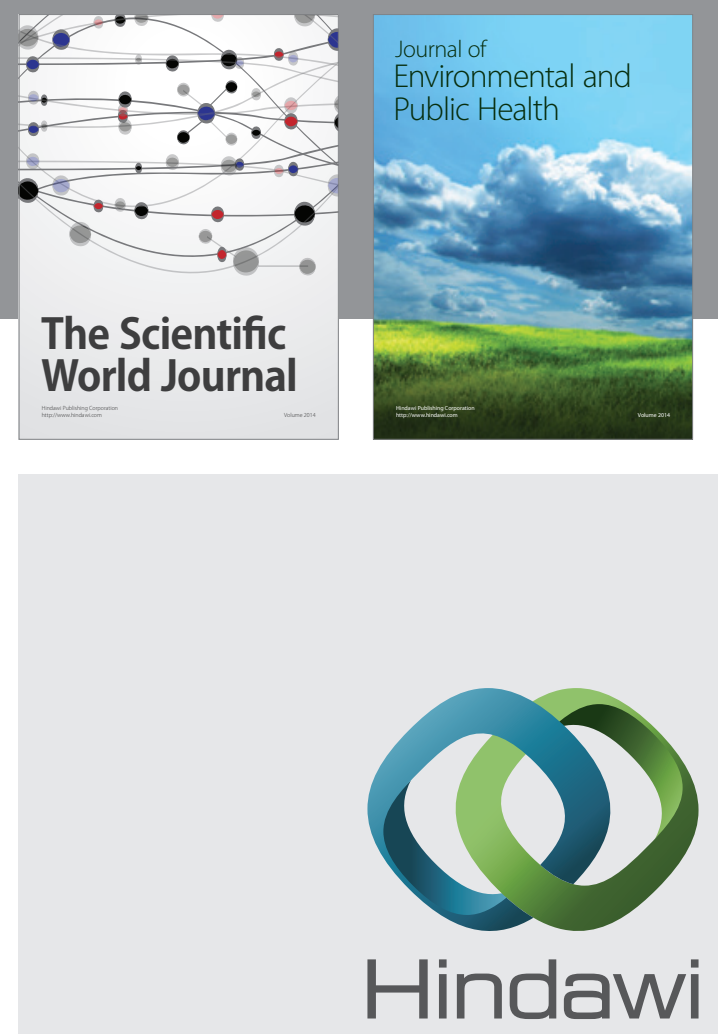

Submit your manuscripts at

http://www.hindawi.com
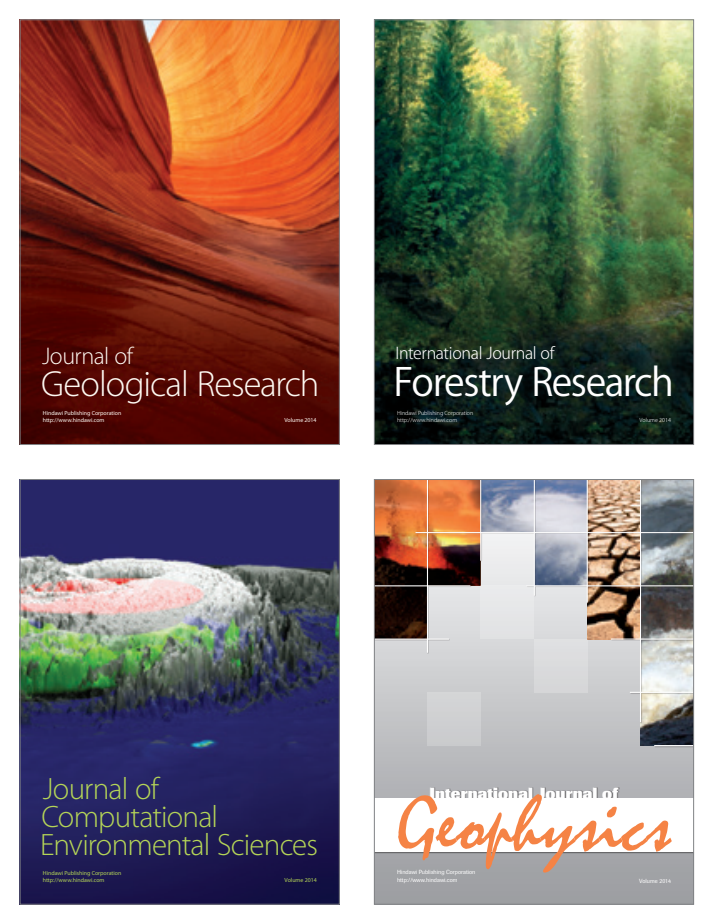
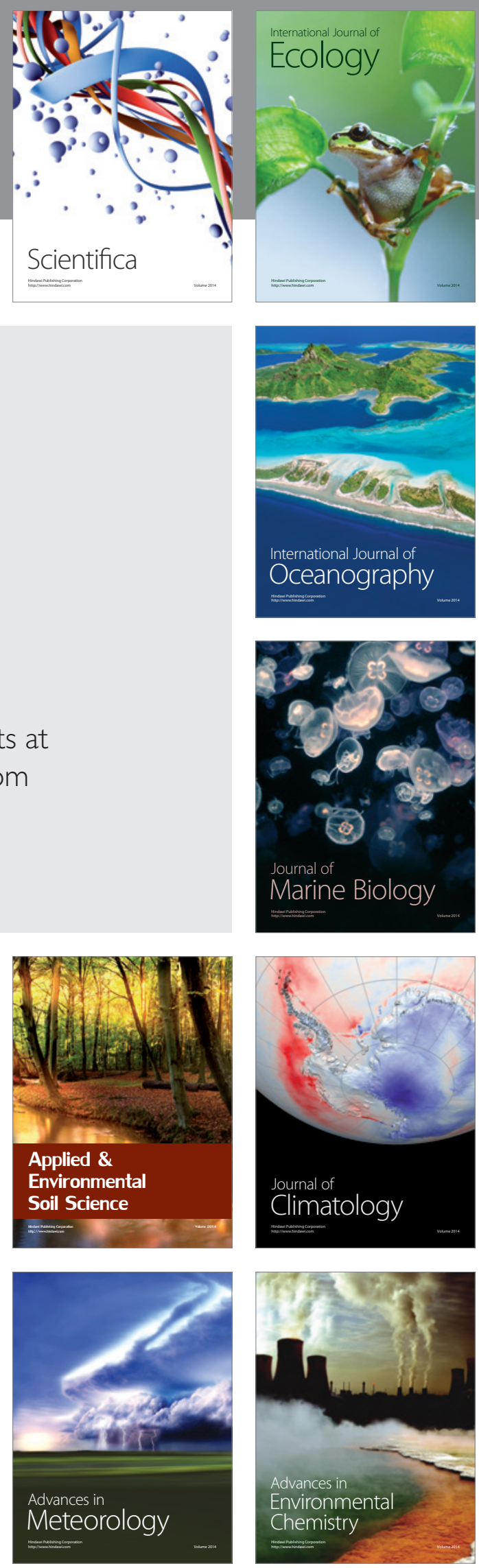